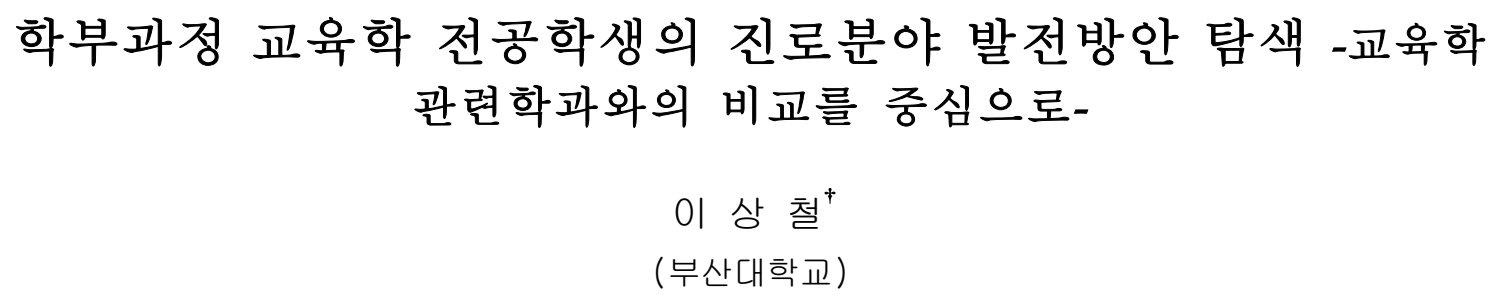

\title{
A Study on the Career Development Plan for the Education Major Students in Korean Universities
}

\author{
Sang-Chul $\mathrm{LEE}^{\dagger}$ \\ (Pusan National University)
}

\begin{abstract}
The purpose of this study is to analyze current state of education departments in Korean universities and to find out ways to help education major students shape their future career. The findings of the study are as follows.

First, the comparative analysis of the current state of education and education-related departments showed that average employment rate of education departments in 2011 was $35.0 \%$, whereas that of related departments was $56.6 \%$, which showed a significant difference. Second, education courses were specialized in areas such as lifelong educator qualifications, teaching certificates in morality/ethics, corporate HRD(human resource development), etc. in case of education departments. In case of education-related departments, education courses were specialized in areas such as teaching certificates in pedagogy, lifelong educator qualifications, license of school counselor, corporate HRD, etc. Though there were many overlapping areas, specialization was relatively more common and diverse in education-related departments.

Next, to help students shape their future career, developments in specialized career courses, new career fields, and career education models were suggested. To give shape to the progress plans, the development of standard education courses for student careers, the introduction of certification system about course specialization, and search for the career path of teaching profession which allows utilization of the knowledge of education were suggested.
\end{abstract}

Key words : Department of education, Career education, Curriculum specialization

$$
\text { I. 서 론 }
$$

대학교육의 목적은 학문의 자유를 통한 교양교
육과 삶의 핵심을 차지하는 직업교육의 대립을 극복하고 양자의 조화를 이루는데 있으며, 직업 은 개인의 삶의 이상 실현에 중요한 의의를 가진

† Corresponding author : 051-510-2637, 1sc2203@hanmail.net

* 이 논문은 2011년 제9회 효원교육포럼(대학교육의 혁신과 과제, 2011.12.28)에서 발표한 내용을 기 초로 하여 발전시킨 것임.

$$
-670-
$$


다(박철홍, 2006). 그러므로 대학에서 교육학을 전공한다는 것은 교육학 교육을 평생의 직업으로 삼거나, 교육학을 전문적으로 연구할 수 있는 학 문공동체의 일원이 될 수 있는 것이다(황정규, 1991). 그 동안 교육학과는 교직과목을 통해 교사 의 직무수행에 필요한 전문적 자질과 능력을 제 고하는데 중요한 역할을 수행해 왔을뿐 아니라 수많은 중등 교사를 배출해 왔다. 그러나 저출산 으로 인한 교사 수요의 급격한 감소와 아울러, 최근에는 교원양성과정에서 교직과목의 비중을 축소하여 교과교육학으로 대체하는 움직임과 교 원임용시험에서 교육학 과목의 존폐 논란 등으로 인하여, 교원양성과 임용과정에서 교육학의 위상 이 급격하게 변화되고 있다(이종승, 2011).

학부과정 교육학과는 현재 38 개 대학에 개설되 어 있으며 입학정원은 1,046 명이고, 졸업과 동시 에 교육학 2급 정교사 교원자격증을 취득할 수 있지만 최근 5년간 교원임용시험에서 교육학 교 과 선발인원은 없다. 각 대학 교육학과에서는 전 공학생의 진로분야를 교육학 및 복수전공을 통한 교직 진출, 평생교육사 자격증 취득 후 평생교육 시설 등과 같은 사회교육기관 진출, 기업체 교육 훈련을 담당하는 $\mathrm{HRD}$ 분야 진출, 대학원 진학을 통한 대학교원 및 연구원 진출 등과 같이 다양하 게 제시하여, 교육학 전공학생의 진로 분야가 교 직에 제한되지 않음을 안내하고 있다. 졸업 후 진로분야의 다양함에도 불구하고 2011년 기준 전 국 교육학과 평균 취업률은 $35.0 \%$ 에 머물고 있으 며, 4년제 대학 학부과정 학과 분류(강성국 외, 2009)에 따라 교육학 하위 전공으로 특성화된 교 육공학과, 교육심리학과, 평생교육학과 등과 같은 교육학 관련학과의 2011년 평균 취업률 $56.6 \%$ 에 비해 상당히 낮다.

교육학의 사회적 영향력과 학문적 발전에 관한 활발한 논의에 비해, 학부과정 교육학 전공학생 의 진로탐색은 개별 학과 차원에 머물고 있는 등 체계적으로 이루어지지 못하고 있다. 학부과정에 관한 연구도 교육과정 개선에 중점을 둔 연구(김
재춘·김재현, 2008 ; 김현우, 1997 ; 송숙경 외, 2010)에 그치고 있으며, 이들 연구에서 복수전공 관련 교육과정 개선의 필요성을 언급하고 있으나 학생들의 다양한 진로와 연계하여 교육과정을 어 떻게 개선해야 하는지에 대한 구체적인 방안을 제시하고 있지는 않다. 이와는 달리, 학부과정에 개설된 개별 학과의 발전에 대한 연구는 법학(정 용상, 2011), 상담학(김인규, 2009), 세무학(최임수. 최경식, 2010), 수산.해운계열 사범계 학과(이종호, 2008), 체육학(김흥백.김상태, 2005), 행정학(조경 호, 2005) 등의 학과를 중심으로 진행되었다. 이 들 연구는 공통적으로 시대 흐름에 맞는 전공선 택 교과목의 확대, 교육프로그램의 다양화, 현장 요구를 반영한 실무교육 확대, 교육과정 인증제 를 통한 신뢰성 확보, 학생의 진로를 고려한 맞 춤형 교육과정 편성체제 구축, 학생 중심의 체계 적인 진로지도 강화 등과 같이 학생의 직업진로 준비와 관련한 교육과정 변화의 필요성을 학과의 발전방안으로 제시하고 있다는 점에서 시사하는 바가 크다.

그 동안 대학교육은 학문추구를 주된 목적으로 이루어져 왔지만, 대학 진학률의 상승과 취업률 의 하락 등으로 인하여 직업교육의 필요성이 추 가되고 있다(김성국, 2000). 직업교육의 필요성을 중시하는 입장에서, 대학교육은 학생의 취업 지 원, 직업세계가 요구하는 지식 제공, 학생이 희망 하는 직업에 필요한 지식 습득 지원(목진휴 외, 2009)과 더불어 학과 교육과정과 수업방식의 변 화를 필요로 한다(채창균·김태기, 2009). 최근 대 학 졸업자의 취업난과 높은 교원임용시험 경쟁률 로 인하여 교육학과 학생들의 취업이 한층 어려 워진 시기에, 교육학 전공학생의 진로분야에 관 한 논의는 학부과정 교육의 개선을 위해 의미있 는 기회가 될 수 있을 것이다.

이에 본 연구에서는 전국 대학의 학부과정에 개설된 교육학 전공학생의 진로분야에 대한 발전 방안을 탐색하고자 한다. 연구의 목적을 달성하 기 위하여, 첫째, 교육학 전공학생의 진로관련 시 
사점을 찾기 위해 교육학과 및 교육학 관련학과 의 설치, 전공학생 진로분야, 취업 및 진학, 교육 과정 특성화 현황을 비교분석하며, 둘째, 이와 같 은 연구결과를 바탕으로 교육학 전공학생의 진로 분야 발전방안을 학생들의 직업준비와 연관지어 살펴보고자 한다.

\section{II. 교육학과 및 교육학 관련학과 현황}

\section{1. 설치현황}

가. 교육학과 설치 현황

학부 교육학과 설치 현황은 <표 $1>$ 과 같이 설 립별 및 입학정원수, 지역별, 학과소속대학 등을 중심으로 살펴볼 수 있다.

<표 1> 학부 교육학과 설치현황(2011년)

\begin{tabular}{|c|c|c|c|c|}
\hline \multicolumn{2}{|c|}{ 지역 대학 } & $\begin{array}{c}\text { 국립 } \\
\text { (입학정원수) }\end{array}$ & $\begin{array}{c}\text { 사립 } \\
\text { (입학정원수) }\end{array}$ & 학교수 \\
\hline \multirow[t]{6}{*}{ 시 } & 서울 & 서울대(12) & $\begin{array}{l}\text { 고려대(44), 국민대(40, 문과대 } \\
\text { 학), 동국대(30), 상명대(30), 성 } \\
\text { 균관대(35), 성신여대(30), 세종 } \\
\text { 대(30, 인문대학), 숙명여대(60, } \\
\text { 문과대학), 연세대( } 54, \text { 교육과학 } \\
\text { 대학), 이화여대(30), 중앙대(34), } \\
\text { 한양대(22), 홍익대(40) }\end{array}$ & 14 개교 \\
\hline & 부산 & 부산대(15) & $\begin{array}{l}\text { 경성대( } 30 \text {, 문과대학), 동아대 } \\
(40, \text { 인문대학), 신라대( } 30)\end{array}$ & 4 개교 \\
\hline & 대구 & 경북대(12) & 계명대(23) & 2 개교 \\
\hline & 인천 & $\cdot$ & 인하대(40) & 1 개교 \\
\hline & 대전 & 충남대(15) & 한남대(35) & 2 개교 \\
\hline & 광주 & 전남대(15) & 조선대(20, 2010년 신설) & 2 개교 \\
\hline \multirow{8}{*}{ 도 } & 경기 & $\cdot$ & 강남대(40) & 1 개교 \\
\hline & 강원 & 강원대(15) & . & 1 개교 \\
\hline & 충북 & 충북대(15) & 서원대(40) & 2개교 \\
\hline & 충남 & 공주대(15) & $\cdot$ & 1 개교 \\
\hline & 전북 & 전북대(15) & 우석대(20), 원광대(20) & 3개교 \\
\hline & 전남 & $\begin{array}{l}\text { 목포대(15, } \\
\text { 인문대학) }\end{array}$ & $\cdot$ & 1 개교 \\
\hline & 경북 & $\cdot$ & 대구가톨릭대(10), 영남대(30) & 2 개교 \\
\hline & 경남 & 경상대(15) & 경남대(30) & 2개교 \\
\hline \multicolumn{2}{|c|}{ 합계 } & 11 개교(159) & 27개교(887) & $\begin{array}{l}38 \text { 개교 } \\
(1,046)\end{array}$ \\
\hline
\end{tabular}

자료 : 김재춘 - 김재현(2008). 교육학과 교육과정의 편성 실태 분석 및 개선 방안 탐색. 교육과학연구, 39(3), p.114 수정보완.
첫째, 설립별 및 입학정원수는 국립 11개교 159 명, 사립 27개교 887명으로 전체 38 개 대학에 입학정원수는 1,046 명이다. 설립 및 입학정원수에 서 국립보다 사립의 비중이 매우 높고, 특히 학 과별 입학정원수는 최소 12 명부터 최대 60 명까지 큰 차이를 보이고 있다. 둘째, 지역별로는 서울권 14 개교, 인천·경기권 2 개교, 강원권 1 개교, 충청권 5 개교, 전라권 6 개교, 경상권 10 개교에 설치되어 있으며, 서울권과 경상권의 비중이 상대적으로 높은 편이다. 셋째, 학과 소속대학은 사범대학이 31 개교, 비사범대학이 7 개교로 나타났고, 비사범 대학은 인문대학 3 개교, 문과대학 3 개교, 교육과 학대학 1 개교였다.

나. 교육학 관련학과 설치 현황

학부 교육학 관련학과 설치 현황은 <표 2>와 같이 개설학과 및 대학, 설립별, 학과소속대학, 입학정원수 등으로 살펴볼 수 있다.

<표 2> 학부 교육학 관련학과 설치현황(2011년)

\begin{tabular}{c|c|c|c|c|c}
\hline \multirow{2}{*}{ 주요현황 } & \multicolumn{2}{|c|}{ 설립별 } & \multirow{2}{*}{ 소속 } & \multirow{2}{*}{ 입학 } \\
\cline { 2 - 4 } 학과 및 댄훤수
\end{tabular}

개설학과 및 대학으로 교육공학과는 건국대, 안동대, 이화여대, 한양대 4 개교, 교육심리학과는 서울여대 1 개교, 평생교육학과는 동의대와 숭실 대 2개교 등 전체 7 개교에 설치되어 있고, 설립 별로는 국립대가 1 개교, 사립대가 6 개교이며, 학 과소속대학은 사범대학 4 개교, 인문대학 2 개교, 사회과학대학 1 개교이고, 전체 입학정원수는 189 명이다.

교육학과 및 교육학 관련학과 설치 현황을 종 합 정리하면, 첫째, 교육학과는 38 개 대학에 입학 
정원수는 1,046 명인데 비해 교육학 관련학과는 7 개 대학에 입학정원수는 189 명으로 설치 규모와 입학정원수에 있어 상당한 차이가 있고, 둘째, 교 육학과는 사범대학 소속이 38 개교 중 31 개교, 교 육학 관련학과는 7 개교 중 4 개교로 사범대학 비 중이 높았으며, 셋째, 교육학 관련학과 중 이화여 대와 한양대는 교육학과와 교육공학과를 함께 설 치하고 있는 반면, 나머지 5개 대학은 교육학과 가 없는 대학에 설치되어 있다.

\section{2. 전공학생 진로분야}

가. 교육학과 전공학생 진로분야

전국 교육학과 홈페이지에서 제시하고 있는 교 육학 전공학생의 진로분야를 살펴보면 다음과 같 다. 첫째, 중등학교 교직 진출이다. 교육학 또는 복수(부)전공으로 국어, 영어, 수학 등과 같은 교 과 관련 교원자격증을 취득하여 국·공립학교 교 원임용시험이나 사립학교 교원 채용시험에 응시 하여 교직으로 진출할 수 있다. 많은 대학에서 졸업생의 상당수가 중등학교 교직으로 진출하고 있음을 안내하고 있으며, 재학생의 임용시험 준 비를 위한 다양한 프로그램을 운영하고 있다고 밝히고 있다.

둘째, 사회교육기관 전문요원 진출이다. 사회교 육기관 전문요원은 평생교육관련 교과목을 이수 함으로써 평생교육사 자격증을 취득하고, 이를 바탕으로 평생교육단체, 평생교육시설 등에서 교 육 프로그램을 개발하거나 훈련을 담당하는 역할 을 수행한다. 각종 사회교육기관으로 진출하기 위해서는 평생교육사 자격증이 필수적으로 요구 된다고 안내하고 있다.

셋째, 기업체 $\mathrm{HRD}$ 분야 진출이다. 기업체 $\mathrm{HRD}$ 분야에서는 기업체의 인력개발원, 교육연수 원 등에서 교육 프로그램을 개발하거나 교육훈련 을 담당하는 역할을 수행한다. 기업체 HRD 분야 로의 진출을 위해서는 $\mathrm{HRD}$ 관련 교과목을 이수 해야 한다고 강조하고 있다.
넷째, 대학원 진학이다. 대학원 진학을 통해 교 육학에 대한 심화교육을 받을 수 있으며, 석사 및 박사학위를 취득함으로써 대학교수, 각종 교 육연구기관의 연구원, 기업체 $\mathrm{HRD}$ 전문가, 사회 교육기관 전문상담요원, $\mathrm{e}$-러닝 교수설계전문가 등으로 진출할 수 있다. 대학원 진학을 위해서는 교육학의 영역별 세부전공과 관련된 기초과목을 필수적으로 이수해야 한다고 안내하고 있다.

그 밖에 교육행정직 공무원, 청소년상담사 및 지도사, 교육컨설턴트, 다문화교육 전문가, 사회 조사분석사, 교육용 소프트웨어 개발자, 교육출판 전문가, 교육언론방송인 등 다양한 분야로 진출 할 수 있다고 제시하고 있다.

교육학 전공학생의 진로분야 특징으로는, 첫째, 진로분야의 범위와 유형을 상당히 넓고 다양하게 제시하고 있다. 중등학교 교직뿐 아니라 사회교 육기관 전문요원, 기업체 $\mathrm{HRD}$ 분야, 대학원 진 학, 교육행정직 공무원, 청소년상담사 등으로 진 출할 수 있다고 안내함으로써, 학생들의 진로가 교직에 제한되지 않는다는 점을 강조하고 있다. 둘째, 자격증 취득과 같은 전문성을 강조하고 있 다. 사회교육기관 전문요원으로 진출하기 위해서 는 평생교육사 자격증이 반드시 필요하며, 기업 체 $\mathrm{HRD}$ 분야 등으로의 진출을 위해서도 관련 교과목 등을 이수함으로써 전문성을 확보해야 한 다고 밝히고 있다.

나. 교육학 관련학과 전공학생 진로분야

전국 교육학 관련학과 홈페이지에서 제시하고 있는 전공학생의 진로분야를 살펴보면 다음과 같 다. 첫째, 교육공학과의 진출 분야이다. e-러닝 관 련 전문성을 바탕으로 대학의 교수-학습지원센터 또는 ICT 센터, 교육용 소프트웨어 개발 업체, 사이버대학 등으로 진출하여 교육프로그램을 개 발하거나 관리하는 역할을 수행할 수 있고, $\mathrm{HRD}$ 분야 전문성을 바탕으로 기업체 등으로 진출하여 기업교육을 설계하고 운영하는 기업교육전문가로 활동할 수 있으며, 평생교육사 자격증을 취득하 
여 평생교육 관련 기관에서 교육공학 전문성을 활용할 수 있고, 교육학 및 교과 교육 복수전공 을 통하여 중등학교 교직으로 진출할 수 있다고 안내하고 있다.

둘째, 교육심리학과의 진출 분야이다1). 전문상 담교사 자격증을 취득하여 상담교사로 진출할 수 있고, 종합병원 및 개인병원의 아동심리치료 관 련 전문가 즉 상담임상심리 전문가로 활동할 수 있으며, 대학원 진학을 통하여 대학교수 및 교육 연구기관의 연구원으로 진출할 수 있고, 교과 복 수전공을 통하여 일반교사로 진출할 수 있다. 그 밖에 가족 상담 분야, 학습부진 및 특수 교육 분 야, 기업교육 분야, 청소년 및 여성교육 분야, 노 인교육 분야, 공무원 등의 진로를 안내하고 있다.

셋째, 평생교육학과의 진출 분야이다. 평생교육 사 자격증 취득과 같은 전문성을 바탕으로 시.도 청 및 교육청 평생학습관, 문화센터, 학교부설 평 생교육원, 기업체 등과 같은 평생교육분야로 진 출할 수 있고, 청소년지도사 자격증 취득으로 청 소년 수련원, 복지관, 청소년 기관 등과 같은 청 소년 분야로 진출할 수 있으며, 전문상담교사 자 격증을 취득하여 중등학교 상담교사로 진출할 수 있고, $\mathrm{HRD}$ 관련 교과목을 이수함으로써 기업교 육전문가로 활동할 수 있다.

교육학 관련학과 전공학생의 진로분야의 특징 으로는, 첫째, 교육공학과는 공통적으로 e-러닝 분야, $\mathrm{HRD}$ 분야, 교직 분야를 주요 진출 분야로 안내하고 있으나, 이화여대를 제외한 3개 대학은 평생교육 분야를 포함하고 있다. 둘째, 교육심리 학과는 전문상담교사, 상담.임상심리 전문가 등과 같은 상담분야 진출을 강조하고 있다. 셋째, 평생 교육학과는 공통적으로 평생교육 분야를 주요 진 출 분야로 안내하고 있으나, 대학에 따라 $\mathrm{HRD}$ 전문가, 청소년지도사, 전문상담교사 등을 제시하 고 있다.

1) 서울여대 교육심리학과 홈페이지

(http://www.swep.co.kr)
교육학과 및 교육학 관련학과 전공학생의 진로 분야를 종합하면, 첫째, 졸업생들의 주요 진출 분 야가 거의 일치한다는 점이다. 교육학과 및 교육 학 관련학과가 공통적으로 교직, 평생교육, 기업 체 $\mathrm{HRD}$ 등의 분야로 진출할 수 있다고 안내하 고 있어 진로분야가 중복되고 있으며, 이로 인해 교육학과와 교육학 관련학과가 취업에 있어 서로 경쟁관계가 되고 있다고 여겨진다. 둘째, 교육학 과에 비해 교육학 관련학과의 진로 중에서 특성 화된 분야가 있다. 예를 들면, 교육공학과는 e-러 닝, 기업체 $\mathrm{HRD}$ 분야를, 교육심리학과는 전문상 담교사, 상담.임상심리전문가 등의 상담분야를, 평생교육학과는 평생교육전문가, 청소년지도사, $\mathrm{HRD}$ 전문가 등으로 진출할 수 있다는 점을 강 조하고 있다. 교육학과와 교육학 관련학과의 진 로 분야가 다소 중복되는 측면도 있지만, 교육학 과의 진로분야가 상당히 넓고 다양하게 즉 백화 점식으로 안내되고 있는데 비해, 교육학 관련학 과는 특성화를 통하여 전문성을 심화할 수 있다 는 점을 강조한다는 측면에서 차이를 발견할 수 있다.

\section{3. 취업 및 진학 현황}

가. 교육학과 취업 및 진학 현황

교육학과 취업률 현황은 <표 3>과 같이 대학 알리미2)에 공개된 2008년부터 2011년까지의 4년 간 자료를 중심으로 살펴볼 수 있다.

교육학과 전체 평균 취업률은 2008년 $52.4 \%$, 2009년 52.9\%, 2010년 30.3\%, 2011년 35.0\%이며

2) 대학알리미(http://www.academyinfo.go.kr)에 공개된 취업률 은 모든 건강보험 $\mathrm{DB}$ 연계 취업률을 포함하기 때문에 전공일 치 및 정규직 여부, 교직, 사회교육기관, 기업체 등과 같은 구 체적인 취업현황을 파악할 수 없다는 어려움과 더불어, 최근 대학의 취업률 부풀리기(경향신문, 2012.7.26)와 같이 취업률 지표를 $100 \%$ 신뢰할 수는 없다는 한계가 있다. 대학 지원자 및 학부모들이 취업률을 학과 선택의 중요한 기준의 하나로 간주하고 있음을 고려할 때, 대학정보공시제도의 신뢰성 제고 를 위해서는 보다 상세한 취업현황을 제공할 필요가 있으며, 학과 차원에서도 구체적인 취업현황을 홈페이지에 안내할 필 요가 있다. 
4년 평균 취업률은 $42.7 \%$ 이다. 세부적으로 살펴 보면, 설립별 취업률은 2011년 국립대 평균이 $25.9 \%$, 사립대 평균이 $37.4 \%$ 로 다소 차이가 있으 며, 소속대학별 취업률은 2011년 비사범대소속 평균이 $39.9 \%$, 사범대 소속 평균이 $32.6 \%$ 로 나타 났다. 취업률 현황의 특징으로는, 2011년 기준 취 업률에 대학간 차이가 있으며, 일부 사립대 및 비사범대에 소속된 대학의 취업률이 상대적으로 높은 편이다.

교육학과 전체 대학원 진학자수는 2008년 62 명, 2009년 90명, 2010년 75명, 2011년 91명으로 평균 80명선을 유지하고 있고, 2011년 입학정원 대비 대학원 진학률은 $8.7 \%$ 이다. 구체적으로는 고려대, 연세대, 서울대 등 서울지역에 위치한 대 학의 진학자수가 많은 반면, 지방에 소재한 대학 은 연평균 1 2명 정도에 그치고 있다. 대학원 진학 현황의 특징으로는, 서울지역 대학 및 사립 대학을 중심으로 진학자가 상대적으로 많은 반 면, 지역 거점 국립대의 진학자가 상당히 적은 수준에 머물고 있다는 점이다.

$<$ 표 3> 교육학과 취업률 및 진학자 현황

(2008 2011년)

\begin{tabular}{|c|c|c|c|c|c|c|c|c|c|c|c|}
\hline \multirow{3}{*}{\multicolumn{2}{|c|}{$\begin{array}{l}\text { 진로현황 } \\
\text { 설립 및 대학 }\end{array}$}} & \multicolumn{5}{|c|}{ 취업률 } & \multicolumn{5}{|c|}{ 진학자수 } \\
\hline & & 2008 & 2009 & 2010 & 2011 & 4년 & 2008 & 2009 & 2010 & 2011 & 4년 \\
\hline & & 년 & 년 & 년 & 년 & 평균 & 년 & 년 & & 년 & 합계 \\
\hline \multirow{12}{*}{$\begin{array}{l}\text { 국 } \\
\text { 립 }\end{array}$} & 강원대 & 55.0 & 71.4 & 25.0 & 36.4 & 47.0 & 0 & 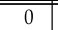 & 0 & 2 & 2 \\
\hline & 경북대 & 6.3 & 11.1 & 30.8 & 33.3 & 20.4 & 0 & 3 & 1 & 0 & 4 \\
\hline & 경상대 & 55.0 & 76.5 & 26.7 & 28.6 & $\begin{array}{ll}46.7 \\
\end{array}$ & 0 & 1 & 0 & 1 & 2 \\
\hline & 공주대 & 90.9 & 84.6 & 37.5 & 42.9 & 64.0 & 1 & 1 & d & 0 & 2 \\
\hline & 목포대 & 75.0 & 71.4 & 36.4 & 4.4 & 56.8 & 0 & 0 & d & 0 & 0 \\
\hline & 부산대 & 27.3 & 36.4 & 9.1 & 25.0 & 24.5 & 2 & 6 & 2 & 2 & 12 \\
\hline & 서울대 & 66.7 & 30.0 & 69.2 & 44.4 & 52.6 & 9 & 4 & 10 & 10 & 33 \\
\hline & 전남대 & 10.0 & 26.3 & 6.7 & 12.5 & 13.9 & 0 & 0 & 0 & 0 & 0 \\
\hline & 전북대 & 73.7 & 38.5 & 63.6 & 23.1 & $\begin{array}{l}49.7 \\
\end{array}$ & 0 & 0 & 1 & 0 & 1 \\
\hline & 충남대 & 50.0 & 20.0 & 33.3 & 14.3 & 29.4 & 3 & 1 & o & 1 & 5 \\
\hline & 충북대 & 33.3 & 61.1 & 0.0 & 20.0 & 28.6 & 0 & 1 & d & 0 & 1 \\
\hline & 평균(계) & 49.4 & 47.9 & 30.8 & 25.9 & 39.4 & 15 & 17 & 14 & 16 & 62 \\
\hline \multirow{11}{*}{$\begin{array}{l}\text { 사 } \\
\text { 립 }\end{array}$} & 강남대 & 67.3 & 66.7 & 38.5 & 53.2 & 56.4 & 3 & 6 & 4 & 2 & 15 \\
\hline & 경남대 & 45.6 & 65.9 & 29.0 & 48.3 & 47.2 & 2 & 3 & 1 & 2 & 8 \\
\hline & 경성대 & 51.2 & 47.2 & 40.0 & 43.5 & 45.5 & 1 & 0 & 1 & 2 & 4 \\
\hline & 계명대 & 27.8 & 44.2 & 27.6 & 45.0 & 36.2 & 4 & 1 & 3 & 5 & 13 \\
\hline & 고려대 & 68.8 & 62.2 & 28.6 & 41.5 & 50.3 & 5 & 13 & 11 & 13 & 42 \\
\hline & 국민대 & 38.2 & 39.1 & 31.3 & 33.3 & 35.5 & 1 & 0 & d & 5 & 6 \\
\hline & $\begin{array}{l}\text { 대구가 } \\
\text { 톨릭대 }\end{array}$ & 46.2 & 66.7 & 42.3 & 41.2 & 49.1 & 1 & 0 & 1 & 0 & 2 \\
\hline & 동국대 & 34.3 & 38.7 & 9.4 & 34.3 & 29.2 & 1 & 1 & 2 & 2 & 6 \\
\hline & 동아대 & 42.9 & 53.8 & 7.7 & 43.8 & 37.1 & 0 & 2 & d & 5 & 7 \\
\hline & 상명대 & 61.1 & 42.1 & 9.1 & 25.8 & 34.5 & 0 & d & d & 1 & 1 \\
\hline & 서원대 & 54.5 & 51.2 & 27.1 & 42.1 & 43.7 & 0 & 0 & d & 0 & 0 \\
\hline
\end{tabular}

\begin{tabular}{|c|c|c|c|c|c|c|c|c|c|c|}
\hline 성균관대 & 37.9 & 27.6 & 24.0 & 38.7 & 32.1 & 1 & 2 & d & 2 & 5 \\
\hline 성신여대 & 51.5 & 85.2 & 7.7 & 25.0 & 42.4 & 0 & 1 & 0 & 2 & 3 \\
\hline 세종대 & 46.2 & 46.7 & 52.4 & 57.7 & 50.8 & 0 & 0 & 1 & 0 & 1 \\
\hline 숙명여대 & 38.5 & 34.4 & 67.3 & 47.1 & 46.8 & 7 & 7 & g & 6 & 29 \\
\hline 신라대 & 70.4 & 75.0 & 72.0 & 48.5 & 66.5 & 1 & 1 & d & 0 & 2 \\
\hline 연세대 & 50.8 & 51.1 & 41.7 & 49.2 & 48.2 & 5 & 13 & 10 & 11 & 39 \\
\hline 영남대 & 75.8 & 76.7 & 12.9 & 13.3 & 44.7 & 1 & 1 & d & 0 & 2 \\
\hline 우석대 & 78.6 & 58.3 & 33.3 & 11.1 & 45.3 & 0 & 1 & 2 & 2 & 5 \\
\hline 원광대 & 71.1 & 78.3 & 24.4 & 43.2 & 54.3 & 1 & 2 & d & 0 & 3 \\
\hline 이화여대 & 84.6 & 66.7 & 27.5 & 45.0 & 56.0 & 1 & 6 & 3 & 2 & 12 \\
\hline 인하대 & 57.5 & 39.5 & 22.0 & 20.0 & 34.8 & 5 & 6 & 4 & 0 & 15 \\
\hline 중앙대 & 50.0 & 45.2 & 22.2 & 25.9 & 35.8 & 2 & 2 & 5 & 4 & 13 \\
\hline 한남대 & 69.8 & 65.6 & 22.2 & 20.7 & 44.6 & 0 & 0 & 3 & 5 & 8 \\
\hline 한양대 & 44.8 & 56.5 & 42.3 & 41.7 & 46.3 & 3 & 3 & 0 & 2 & 8 \\
\hline 홍익대 & 29.4 & 45.5 & 20.0 & 32.0 & 31.7 & 2 & 2 & 1 & 2 & 7 \\
\hline 평균(계) & 53.6 & 55.0 & 30.1 & 37.4 & 44.0 & 47 & 73 & 61 & 75 & 256 \\
\hline 전체평균(합계) & 52.4 & 52.9 & 30.3 & 35.0 & 42.7 & 62 & 90 & 75 & 91 & 318 \\
\hline
\end{tabular}

자료 : 대학알리미(http://www.academyinfo.go.kr)

나. 교육학 관련학과 취업 및 진학 현황

교육학 관련학과의 취업률 현황은 <표 $4>$ 와 같이 대학알리미에 공개된 2008년부터 2011년까 지의 4 년간 자료를 중심으로 살펴볼 수 있다. 교 육학 관련학과의 전체 평균 취업률은 2008년 71.5\%, 2009년 66.2\%, 2010년 51.4\%, 2011년 $56.6 \%$ 이며 4 년 평균 취업률은 $61.4 \%$ 이다. 세부적 으로 살펴보면, 2011년도 취업률을 기준으로 건 국대 교육공학과 $40.7 \%$, 안동대 교육공학과 $63.2 \% 3)$, 이화여대 교육공학과 $64.0 \% 4)$, 한양대 교 육공학과 $55.6 \%$ 로 교육공학과 평균은 $55.9 \%$ 이고, 서울여대 교육심리학과는 $47.8 \%$ 이며, 동의대 평 생교육학과는 $57.5 \% 5)$, 숭실대 평생교육학과는 $67.7 \%$ 로 평생교육학과 평균은 $62.6 \%$ 이다. 취업률 현황의 특징으로는, 학과별 취업률은 평생교육과,

3) 안동대 교육공학과 홈페이지에서는 2009년 기준 졸업생 주요 진로 현황으로 대기업 $24 \%$, 교육컨설팅업체 $24 \%$, e-러닝업체 $20 \%$, 사이버대학 $12 \%$, 대학원 진학 $12 \%$, 공공기관 $8 \%$ 등이 라고 안내하고 있다.

(http://home.andong.ac.kr/edutech)

4) 이화여대 교육공학과 홈페이지에서는 졸업생들의 주요 진로 분야로 IT 멀티미디어업계, 교육계, 학계, 박사과정 진학, 기 업체, 방송계 등의 순으로 진출하고 있다고 밝히고 있다 (http://home.ewha.ac.kr/ et).

5) 동의대학교 평생교육학과 홈페이지에서는 2011년 기준 졸업 생 취업률은 $75 \%$ 이고, 주요 진로 현황으로 청소년 수련관, 문 화센터, 학교부설 평생교육원, 기타 평생교육기관, 대학원 진 학, 시·도청 및 교육청 평생학습관, 기업체, 복지관 및 기타 청소년 기관 등의 순으로 진출하고 있다고 안내하고 있다. (http://lifelonged.deu.ac.kr) 
교육공학과, 교육심리학과의 순이었으며, 대학별 로는 숭실대, 이화여대, 안동대의 취업률이 다소 높게 나타났다.

교육학 관련학과의 전체 대학원 진학자수는 2008년 30명, 2009년 28명, 2010년 25명, 2011년 28명으로 평균 25명 이상을 유지하고 있고, 2011 년 입학정원 대비 대학원 진학률은 $14.8 \%$ 이다. 구체적으로는 이화여대, 숭실대, 서울여대의 진학 자수가 상대적으로 높으며, 지방에 소재한 동의 대와 안동대의 진학자수도 연평균 3명 내외를 유 지하고 있다. 대학원 진학 현황의 특징으로는, 전 체적으로 대학원 진학률이 상당히 높은 편이며, 서울 소재 대학과 지방 소재 대학간 진학자수에 있어 큰 차이를 보이지 않고 있다는 점이다.

$<$ 표 $4>$ 교육학 관련학과 취업률 및 진학자 현황 (2008 2011년)

\begin{tabular}{|c|c|c|c|c|c|c|c|c|c|c|c|}
\hline \multirow{2}{*}{\multicolumn{2}{|c|}{ 학과 및로현황학 }} & \multicolumn{5}{|c|}{ 취업률 } & \multicolumn{5}{|c|}{ 진학자수 } \\
\hline & & $\begin{array}{c}2008 \\
\text { 년 }\end{array}$ & $\begin{array}{c}2009 \\
\text { 년 }\end{array}$ & $\begin{array}{c}2010 \\
\text { 년 }\end{array}$ & $\begin{array}{c}2011 \\
\text { 년 }\end{array}$ & $\begin{array}{l}\text { 4년 } \\
\text { 평균 }\end{array}$ & $\begin{array}{c}2008 \\
\text { 년 }\end{array}$ & $\begin{array}{c}2009 \\
\text { 년 }\end{array}$ & $\begin{array}{c}2010 \\
\text { 년 }\end{array}$ & $\begin{array}{c}2011 \\
\text { 년 }\end{array}$ & $\begin{array}{l}\text { 4년 } \\
\text { 합계 }\end{array}$ \\
\hline \multirow{5}{*}{$\begin{array}{l}\text { 교육 } \\
\text { 공 } \\
\text { 학과 }\end{array}$} & 건국대 & 58.5 & 25.8 & 37.5 & 40.7 & 40.6 & 3 & 1 & 0 & 1 & 5 \\
\hline & 안동대 & 78.6 & 76.9 & 57.9 & 63.2 & 69.2 & 3 & 3 & 3 & 2 & 11 \\
\hline & $\begin{array}{l}\text { 이화 } \\
\text { 여대 }\end{array}$ & 81.8 & 93.9 & 42.6 & 64.0 & 70.6 & 9 & 8 & 3 & 11 & 31 \\
\hline & 한양대 & 57.9 & 50.0 & 45.8 & 55.6 & 52.3 & 4 & 6 & 4 & 1 & 15 \\
\hline & 평균(계) & 69.2 & 61.7 & 46.0 & 55.9 & 58.2 & 19 & 18 & 10 & 15 & 62 \\
\hline $\begin{array}{l}\text { 교육 } \\
\text { 심리 } \\
\text { 학과 }\end{array}$ & $\begin{array}{l}\text { 서울 } \\
\text { 여대 }\end{array}$ & 57.5 & 80.0 & 35.5 & 47.8 & 55.2 & 2 & 0 & 6 & 8 & 16 \\
\hline \multirow{3}{*}{$\begin{array}{l}\text { 평생 } \\
\text { 교육 } \\
\text { 학과 }\end{array}$} & 동의대 & 80.0 & 77.8 & 70.4 & 57.5 & 71.4 & 4 & 4 & 4 & 3 & 15 \\
\hline & 숭실대 & 86.4 & 59.1 & 70.0 & 67.7 & 70.8 & 5 & 6 & 5 & 2 & 18 \\
\hline & 평균(계) & 83.2 & 68.5 & 70.2 & 62.6 & 71.1 & 9 & 10 & 9 & 5 & 33 \\
\hline \multicolumn{2}{|c|}{ 전체평균(합계) } & 71.5 & 66.2 & 51.4 & 56.6 & 61.4 & 30 & 28 & 25 & 28 & 111 \\
\hline
\end{tabular}

교육학과 및 교육학 관련학과의 취업 및 진학 현황을 종합하면, 첫째, 교육학과와 교육학 관련 학과는 유사한 학과임에도 불구하고 취업률에 다 소 차이가 있다는 점이다. 2011년 기준 평균 취 업률은 교육학과가 $35.0 \%$ 인데 비해 교육학 관련 학과는 $56.6 \%$ 이며, 참고로 $50 \%$ 이상 취업률을
보이는 대학도 교육학과는 38 개 대학 중 2 개 대 학에 그치는데 비해 교육학 관련학과는 7개 대학 중 5개 대학이었다. 둘째, 진학률에 있어서도, 2011년 입학정원 대비 대학원 진학률은 교육학과 가 $8.7 \%$ 인데 비해 교육학 관련학과는 $14.8 \%$ 로 상당한 차이를 나타내고 있다.

\section{4. 교육과정 특성화 현황}

가. 교육학과 교육과정 특성화 현황

교육학과 진로관련 교육과정 특성화 현황은 <표 5>와 같으며, 구체적인 특성화 분야와 내용 을 살펴보면 다음과 같다.

첫째, 교직관련 특성화 현황으로는 사립 9개 대학에서 도덕·윤리 교원 자격증 취득을 위한 교 육과정을 운영하고 있다. 구체적으로는 학과 교 육과정에 도덕윤리 교육론, 도덕윤리 교재연구 지도법, 도덕윤리과 평가론 등과 같은 교과목을 개설하여 학생들의 진로준비를 지원하고 있으며, 이와 같은 도덕·윤리과 연계전공 운영은 타 학과 에 개설된 교과목을 수강하는 복수전공 및 부전 공과는 차별화된 방식이다.

둘째, 사회교육관련 특성화 현황으로는, 국·사 립을 포함하여 24 개 대학에서 평생교육사 자격증 과정, 3 개 대학에서는 각각 기업체 $\mathrm{HRD}$ 전문가, 다문화교육 전문가, 사회조사분석사 양성을 위한 관련 교육과정을 운영하고 있다. 구체적으로는 학과 교육과정에 평생교육사 자격증 관련 교과목 인 평생교육개론, 평생교육경영학, 성인학습 및 상담론 등의 교과목 개설, 기업체 $\mathrm{HRD}$ 전문가 양성을 위하여 인적자원개발 기초, 교육과 일의 세계, $\mathrm{HRD}$ 와 성인교육 등과 같은 교과목 개설, 다문화교육 전문가 양성을 위하여 다문화 교육 론, 다문화 사회와 교육, 이중언어발달 등과 같은 교과목 개설, 사회조사분석사 양성을 위하여 교 육추리통계, 컴퓨터활용 통계분석, 평가도구 개발 연습 등과 같은 교과목을 개설하여 학생들의 진 로준비를 지원하고 있다. 
학부과정 교육학 전공학생의 진로분야 발전방안 탐색 -교육학 관련학과와의 비교를 중심으로-

<표 5> 교육학과 교육과정 특성화 현황

\begin{tabular}{|c|c|c|c|c|c|c|c|c|}
\hline \multirow{2}{*}{ 대학 } & \multirow[t]{2}{*}{ 특성화 } & \multicolumn{2}{|c|}{ 교직관련 } & \multicolumn{2}{|c|}{ 사회교육관련 } & \multicolumn{2}{|c|}{ 기타 } & \multirow[b]{2}{*}{ 교육과정 특징 } \\
\hline & & $\begin{array}{l}\text { 도덕· } \\
\text { 윤리 } \\
\text { 교사 }\end{array}$ & $\begin{array}{l}\text { 평생 } \\
\text { 교육사 }\end{array}$ & $\begin{array}{c}\text { 기업체 } \\
\mathrm{HRD} \\
\text { 전문가 }\end{array}$ & $\begin{array}{c}\text { 다문화 } \\
\text { 교육 } \\
\text { 전문가 }\end{array}$ & $\begin{array}{c}\text { 사회 } \\
\text { 조사 } \\
\text { 분석사 }\end{array}$ & $\begin{array}{l}\text { 맞춤형 } \\
\text { 진로 } \\
\text { 지도 }\end{array}$ & \\
\hline \multirow{11}{*}{ 국립 } & 강원대 & & O & & & & & 꿈-설계 상담 교과목 개설 \\
\hline & 경북대 & & O & & & & & \\
\hline & 경상대 & & O & & & & & \\
\hline & 공주대 & & O & & & & & 교육학전공(학문연구지향 트랙), 평생교육사 트랙 교과목 제시 \\
\hline & 목포대 & & O & & & & & \\
\hline & 부산대 & & O & & & & & 교육프로젝트 매니지먼트 교과목 개설 \\
\hline & 서울대 & & & & & & & 전공과목 이수표준형태 제시 \\
\hline & 전남대 & & O & & & & & \\
\hline & 전북대 & & O & & & & & \\
\hline & 충남대 & & & & & & & 미래설계상담 교과목 개설 \\
\hline & 충북대 & & O & & & & & \\
\hline \multirow{27}{*}{ 사립 } & 강남대 & & O & & & & & 진로지도상담 교과목 개설 \\
\hline & 경남대 & & O & & & & & 현장실무특강 교과목 개설 \\
\hline & 경성대 & $\mathrm{O}$ & O & & & & & \\
\hline & 계명대 & & & & & 0 & & 사회조사분석사, 심리상담전문가 자격증 준비 \\
\hline & 고려대 & O & O & & & & & \\
\hline & 국민대 & O & O & & & & & \\
\hline & 대가대 & & O & & & & & \\
\hline & 동국대 & . & O & & & & O & 진출분야별 이수교과목 제시 \\
\hline & 동아대 & O & 0 & & & & & \\
\hline & 상명대 & & O & & & & & \\
\hline & 서원대 & & & & & & & \\
\hline & 성균관대 & & & & & & & \\
\hline & 성신여대 & & & & & & & \\
\hline & 세종대 & & O & & & & & 상담·발달심리사, 진로상담사 등 자격증 준비 \\
\hline & 숙명여대 & & & & & & O & $\begin{array}{l}\text { 진출유형에 따른 전공 로드맵 설계도 제시 : 교사, 교육(계)관련 } \\
\text { 기업, 교직원 및 연구원 등 } \\
\text { 희망진로에 따라 추천 교과목 제시 }\end{array}$ \\
\hline & 신라대 & O & O & & & & O & $\begin{array}{l}\text { 직업진로에 따른 교육과정 이수 로드맵 제시 } \\
\text { 진로지도 교과목 개설 }\end{array}$ \\
\hline & 연세대 & & & O & & & & $\begin{array}{l}\mathrm{HRD} \text { 및 산업교육공학 관련 교과목 개설, 인적자원 개발 연수 } \\
\text { 등 } \\
\text { 다양한 전공과목 개설(72교과목 216학점) }\end{array}$ \\
\hline & 영남대 & O & & & & & & \\
\hline & 우석대 & & & & & & & \\
\hline & 원광대 & O & & & & & & 자기계발심층상담 교과목 개설 \\
\hline & 이화여대 & O & & & & & & \\
\hline & 인하대 & O & O & & & & O & $\begin{array}{l}\text { 선택 트랙 시스템(평생교육사) } \\
\text { 교육학 하위영역별 교과목 제시 }\end{array}$ \\
\hline & 조선대 & & & & O & & O & $\begin{array}{l}\text { 희망진로별 트랙 제시 : 교육학 일반트랙(다문화 교육전문가 등), } \\
\text { 복수전공트랙(교과교육전공), 연계전공 트랙(영유아 보육교사, 청 } \\
\text { 소년지도사, 평생교육전문가) } \\
\text { 다문화교육 교과목 개설(7과목) }\end{array}$ \\
\hline & 중앙대 & & 0 & & & & & \\
\hline & 한남대 & & & & & & & \\
\hline & 한양대 & & O & & & & & 다문화교육 교과목 개설(2과목) \\
\hline & 홍익대 & & 0 & & & & & \\
\hline & 합계 & 9 & 24 & 1 & 1 & 1 & 5 & \\
\hline
\end{tabular}

자료 : 대학알리미(http://www.academyinfo.go.kr) 교육과정 요람, 각 대학 및 학과 홈페이지 교육과정 참조

셋째, 맞춤형 진로지도 특성화 현황은 5 개 대 학에서 운영하고 있다. 교직, 교육관련 기업, 교
직원 및 연구원, 사회교육직 등과 같은 진출분야 또는 희망 직업진로에 따른 교육과정 이수 로드 
맵을 제시하여, 학생들이 희망하는 진출유형에 따라 학년별 추천 교과목 등을 제시하여 진로준 비를 지원하고 있다.

마지막으로, 진로관련 교육과정 편성 및 운영 상의 특징으로는 학생 진로탐색을 지원하는 교과 목을 5 개 대학에서 개설하고 있다. 꿈-설계 상담, 미래설계 상담, 진로지도 상담, 진로지도, 자기계 발 심층상담 등을 학기 단위로 개설하고 있으며, 운영상의 특징으로는 최소 4 학기부터 최대 8 학기 까지 매학기 개설하고 있고, pass/fail로 평가하 며, 이수학점은 인정하지 않고 있다.

교육학과의 교육과정 특성화 현황의 특징으로 는, 국·사립 대부분의 대학에서 평생교육사 자격
증 과정을 운영하고 있고, 사립대 및 비사범대소 속 대학을 중심으로 도덕-윤리 교원자격증, 기업 체 $\mathrm{HRD}$ 전문가, 다문화교육 전문가, 맞춤형 진 로지도 등과 같은 진로다양화를 위한 교육과정상 의 노력이 이루어지고 있으며, 학생들의 진로탐 색을 위한 교과목이 학과 또는 대학 차원에서 개 설되고 있다.

나. 교육학 관련학과 교육과정 특성화 현황 교육학과 교육학 관련학과 교육과정 특성화 현 황은 <표 6>과 같으며, 학과와 대학을 중심으로 구체적인 특성화 분야와 내용을 살펴보면 다음과 같다(오경희, 2011).

\section{<표 6> 교육학 관련학과 교육과정 특성화 현황}

\begin{tabular}{|c|c|c|c|c|c|c|c|c|c|}
\hline \multirow{2}{*}{\multicolumn{2}{|c|}{ 학과 }} & \multicolumn{2}{|c|}{ 교직관련 } & \multicolumn{3}{|c|}{ 교육공학관련 } & \multicolumn{2}{|c|}{ 평생교육관련 } & \multirow[b]{2}{*}{ 교육과정 특징 } \\
\hline & & 교육학 & $\begin{array}{l}\text { 전문상 } \\
\text { 담교사 }\end{array}$ & $\begin{array}{l}\text { 기업체 } \\
\text { HRD } \\
\text { 전문가 }\end{array}$ & $\begin{array}{l}\text { e-러닝 } \\
\text { 전문가 }\end{array}$ & $\begin{array}{l}\text { 멀티미 } \\
\text { 디어 } \\
\text { 전문가 } \\
\end{array}$ & $\begin{array}{l}\text { 평생 } \\
\text { 교육사 }\end{array}$ & $\begin{array}{l}\text { 청소년 } \\
\text { 지도사 }\end{array}$ & \\
\hline \multirow{4}{*}{$\begin{array}{l}\text { 교육 } \\
\text { 공학과 }\end{array}$} & 건국대 & & & & 0 & & 0 & & $\begin{array}{l}\text { 희망진로별 교육과정 이수 로드맵 제시(HRD, 평생교육, } \\
\text { 멀티미디어, 교수 · 학습체제개발, 교과교육 분야 등) }\end{array}$ \\
\hline & 안동대 & O & & & O & & 0 & & $\begin{array}{l}\text { 2009년 교육학 교원자격증 교과목 신설 } \\
\text { 2010년 평생교육사 자격증 교과목 신설 }\end{array}$ \\
\hline & 이화여대 & 0 & & & 0 & 0 & & & $\begin{array}{r}\text { 2009년 교과목 신설 } \\
\text { 2011년 교과목 신설 } \\
\text { 멸티미디어 연계 전공 }\end{array}$ \\
\hline & 한양대 & O & & O & O & & O & & $\mathrm{HRD}$ 관련 교과목 다수 개설 \\
\hline $\begin{array}{l}\text { 교육심리 } \\
\text { 학과 }\end{array}$ & 서울여대 & & 0 & & & & & & '자신과 환경에 대한 이해' 교과목 개설 \\
\hline \multirow[b]{2}{*}{$\begin{array}{l}\text { 평생교육 } \\
\text { 학과 }\end{array}$} & 동의대 & & 0 & & & & 0 & o & $\begin{array}{r}\text { 2010년 지도교수 세미나 신설(1 3학년 6학기 개설) } \\
\text { 청소년 연결 평생교육 }\end{array}$ \\
\hline & 숭실대 & & & 0 & & & ○ & & $\begin{aligned} & 1998 \text { 년 국내 최초 학부 } \text { 평생교육학과 설치 } \\
& \text { 기업연결 평생교육 } \\
& \text { 전공과목 영어강좌 개설 }\end{aligned}$ \\
\hline \multicolumn{2}{|c|}{ 합계 } & 3 & 2 & 2 & 4 & 1 & 5 & 1 & \\
\hline
\end{tabular}

첫째, 교육공학과 특성화 현황이다. 건국대는 평생교육사 자격증 및 $\mathrm{e}$-러닝 관련 교과목을 중 심으로 개설하여 교육과정을 운영하고 있으며, 진로지도에 관한 특성으로는 $\mathrm{HRD}$ 및 평생교육, 멀티미디어.WBI, 교수학습체제 개발, 교과교육 분야 등으로 희망진로별 교육과정 이수 로드맵을 제시하고 있다. 안동대는 교육학 교원자격증, 평 생교육사 자격증, 그리고 e-러닝 관련 교과목을
중심으로 개설하여 교육과정을 운영하고 있으며, 구체적으로는 2009학년도에 교육학 교원자격증 교과목, 2010학년도에는 평생교육사 자격증 교과 목을 신설하였다. 이화여대는 교육학 교원자격증, 멀티미디어 연계 전공, 그리고 e-러닝 관련 교과 목을 중심으로 개설하여 운영하고 있으며, 구체 적으로는 2009학년도 이후 거의 매년 교과목을 신설하는 등 교육과정 변화의 폭이 크다6). 한양 
대는 교육학 교원 자격증, 평생교육사 자격증, 기 업체 $\mathrm{HRD}$ 전문가, 그리고 e-러닝 관련 교과목을 중심으로 개설하여 운영하고 있으며, 특이점으로 는 $\mathrm{HRD}$ 관련 교과목을 다수 개설하고 있다는 점이다7).

둘째, 교육심리학과 특성화 현황이다. 국내에서 유일하게 교육심리학과를 설치하고 있는 서울여 대는 전문상담교사 자격증 관련 교과목을 중심으 로 교육과정을 운영하고 있으며, 특이점으로는 2010학년도에 기초학습지도법, 학습진단검사, 교 수행동분석, 부모교육, 청소년상담, 학습동기, 모 래놀이치료, 상담현장실습 교과목, 2011학년도에 는 검사개발, 부모상담, 통합적 사례분석, 교육심 리세미나, 놀이치료, 교육심리 $\mathrm{PBL}$ 교과목을 신 설하는 등 교육과정 변화의 폭이 크다는 점이다.

셋째, 평생교육학과 특성화 현황이다. 동의대는 전문상담교사 자격증, 평생교육사 자격증, 청소년 지도사 자격증 관련 교과목을 중심으로 교육과 정8)을 운영하고 있으며, 특이점으로는 청소년 관 련 평생교육 전문가 양성을 위한 교육과정을 운 영하고, 1 3학년 6학기에 걸쳐 지도교수 세미나 과목을 개설하여 학생들에 대한 진로교육을 실시 하고 있다. 1998년 국내 최초로 학부과정에 평생 교육학과를 설치한 숭실대는 평생교육사 자격증 및 $\mathrm{HRD}$ 관련 교과목9)을 중심으로 교육과정을

6) 이화여대는 2009학년도 기업교육, 교육학논리및논술, 교육학 교과교육론, 미디어리터러시교육, 교육공학인턴십 I · II 교과 목 신설, 2010학년도 교육학교과교재및연구법 교과목 신설, 2011학년도 교수설계스튜디오, 교육조사방법론, 원격교육론 교과목을 신설하였다.

7) 한양대는 $\mathrm{HRD}$ 관련 교과목으로 기업과경영의 이해, $\mathrm{HRD}$ 와 조직변화, 글로벌 $\mathrm{HRD}$ 동향, $\mathrm{HRD}$ 와 창의성개발, $\mathrm{HRD}$ 와 리 더십개발 등을 개설하고 있다.

8) 동의대는 전문상담교사 자격증 취득을 위해 상담이론과 실제, 가족상담, 성인학습 및 상담, 진로상담, 심리검사, 상담실습, 집단상담, 직업정보 등 8 과목 개설, 청소년지도사 자격증 취 득을 위해 청소년 문화, 청소년 복지, 청소년 프로그램 개발 과 평가, 청소년 문제와 보호, 청소년 활동, 청소년 지도방법 론, 청소년 심리 및 상담, 청소년육성제도론 등 8 과목을 개설 하고 있다.

9) 숭실대는 $\mathrm{HRD}$ 관련 교과목으로 인간관계와 커뮤니케이션, 사이버 교수학습체제개발, e-러닝 개발및활용, 경력개발과 조
운영하고 있으며, 평생교육 및 $\mathrm{HRD}$ 전문가 양성 을 목표로 하고 있다.

교육학 관련학과의 교육과정 특성화 현황을 정 리하면, 첫째, 교육학 관련학과 사이에 특성화 영 역이 중복되고 있다. 교육공학과 4 개 대학 중에 서 3 개 대학이 교육학 교원자격증 및 평생교육 사 자격증 교과목을 교육과정에 포함하고 있고, 평생교육학과 중 동의대는 전문상담교사 자격증 교과목을, 숭실대는 다수의 기업체 HRD 관련 교 과목을 교육과정에 개설하고 있다. 둘째, 대학별 로 독창적인 특성화 영역을 개발하고 있다. 이화 여대 교육공학과는 멀티미디어 연계 전공 교과목 을 개설하고 있으며, 동의대 평생교육학과는 청 소년지도사 자격증 관련 교과목을 개설하고 있 고, 숭실대는 기업연결 평생교육전문가 양성을 목표로 관련 교과목을 교육과정에 포함하고 있 다. 교육학 관련학과는 교육공학, 교육심리학, 평 생교육학 등 이미 특성화가 되어 있는 학과임에 도 불구하고 다른 학과 또는 새로운 특성화 영역 을 다양하게 개발하고 있다. 대학 및 학과의 교 육 프로그램 특성화가 신입생의 입학성적, 재학 생의 교육만족도, 졸업생 취업률 등에 효과적이 라는 선행연구(박광식, 2009; 오영재·박행모, 2003; 이주성, 2004)를 고려할 때 교육학 관련학과의 특 성화 노력들이 학생들의 취업률 제고에 어느 정 도 긍정적인 영향을 미치고 있다고 짐작할 수 있 다.

교육학과 및 교육학 관련학과의 교육과정 특성 화 현황을 종합하면, 첫째, 교육학과와 교육학 관 련학과간 특성화 영역이 상당히 중복되고 있다. 대부분의 교육학과 및 교육학 관련학과에서 평생 교육사 자격증 교과목을 개설하고 있으며, 교육 학과는 기업체 $\mathrm{HRD}$ 전문가 교과목을 중점적으 로 개설하고 있는 대학이 있는 반면 교육학 관련 학과는 교육학 교원자격증 교과목을 개설하여 학

직개발, 자기개발과 셀프브랜딩, 직업교육과 실버산업, 기업교 육평가 등을 개설하고 있다. 
생들의 교직 진출 가능성을 탐색하고 있다. 둘째, 교육학과에 비해 교육학 관련학과의 특성화가 활 발하다. 교육학과는 평생교육사 자격증과 도덕·윤 리 교원자격증 과정을 중심으로 특성화가 활발하 고, 기업체 $\mathrm{HRD}$ 전문가, 다문화교육 전문가 등 에 관한 특성화는 일부 대학에서만 교육과정에 포함되어 있는 반면에, 교육학 관련학과는 교육 학 교원자격증, 평생교육사 자격증, 전문상담교 사, 청소년지도사, 멀티미디어 연계, $\mathrm{HRD}$ 와 평생 교육 연계 등 대학별로 다양한 특성화를 시도하 고 있다. 이와 같은 결과를 앞에서 살펴본 각 대 학에서 안내하고 있는 교육학과 및 교육학 관련 학과 전공학생의 진로분야와 관련지어 볼 때, 교 육학과는 진로분야와 실제 교육과정의 불일치가 크게 나타나는 반면, 교육학 관련학과는 진로분 야와 교육과정이 거의 일치하고 있다. 이는 그 동안 교육학과 전공학생의 주요 진로가 교직에 치중되었기 때문에 진로 다양화를 위하여 교육과 정을 특성화하는데는 한계가 있었던 것으로 판단 되지만, 이미 특성화가 되어 있음에도 불구하고 새로운 특성화를 시도하는 교육학 관련학과의 특 성화 진행과정은 시사하는 바가 크다.

\section{III. 교육학 전공학생의 진로분야 발전방안 논의}

지금까지 살펴본 교육학과 및 교육학 관련학과 전공자의 진로분야, 취업 및 진학 현황, 교육과정 특성화 현황을 바탕으로, 교육학 전공학생의 진 로에 대한 발전방안을 논의하면 다음과 같다.

\section{1. 교육과정 특성화 모델 개발}

첫째, 기업체 $\mathrm{HRD}$ 관련 특성화이다. 우수한 인적자원 확보가 급변하는 글로벌 경쟁 환경에서 조직과 기업의 성패를 결정하는 주요 요인으로 부각되고 있는 상황에서, $\mathrm{HRD}$ 는 기업의 미래에 핵심적인 역할을 수행하게 될 것으로 예상되고
있다(최용범·최은수, 2010). 각 대학 홈페이지에는 교육학 전공학생이 기업체 HRD 또는 연수프로 그램을 운영하고 교육하는 전문가로 진출할 수 있다고 안내하고 있지만, 실제 교육과정에서는 평생교육사 자격증 교과목에 해당하는 인적자원 개발론, 기업교육론 등 1 2과목만 개설되어 있 어 이들 과목만으로 기업체 $\mathrm{HRD}$ 전문가로서의 역량을 심화하는데는 한계가 있다. <표 7>에서 보는 바와 같이 $\mathrm{HRD}$ 특성화 대학은 5 개 이상의 교과목을 개설하여 학생들의 전문성 심화를 돕고 있으며, 특히 $\mathrm{HRD}$ 전문가 양성을 목적으로 최근 신설된 창의인재개발학과10)는 $\mathrm{HRD}$ 의 이론과 실 제, 테크놀로지와 $\mathrm{HRD}$, 교육공학과 $\mathrm{HRD}$ 등과 같은 다양한 $\mathrm{HRD}$ 관련 교과목을 개설하여 특성 화된 교육과정을 운영하고 있다. 따라서 기업체 $\mathrm{HRD}$ 전문가 양성을 학과의 주요한 진로분야로 안내하고 있는 대학은 $\mathrm{HRD}$ 관련 교과목, 예를 들면 $\mathrm{HRD}$ 와 성인교육, $\mathrm{HRD}$ 와 조직변화, $\mathrm{HRD}$ 와 창의성개발, $\mathrm{HRD}$ 와 리더십개발, 기업교육 평 가 등을 개설하여 학생들의 진로준비를 지원할 필요가 있다.

둘째, e-러닝 관련 특성화이다. e-러닝은 발전 가능성과 직업적 수요를 창출할 수 있는 진로분 야로 U-러닝 설계자와 U-러닝 튜터를 한국경제 의 차세대 직업으로 제시하고 있다(한국고용정보 원, 2009). e-러닝 또한 교육학과의 실제 교육과정 에는 교육공학, 교수설계, 매체제작실습, 멀티미 디어컨텐츠 개발 등의 교과목을 대학별로 1 2과 목 개설하고 있으나, e-러닝 관련 분야로 진출하 기를 희망하는 학생들이 일부 교과목 수강으로 전문성을 확보하는 데는 어려움이 있다. <표 7> 과 같이 교육공학과는 e-러닝 관련 교과목은 4 10 과목 정도 개설하여 학생들의 전문성을 심화하 고 있듯이, e-러닝 전문가 양성을 주요한 진로분 야로 안내하고 있는 대학은 e-러닝 관련 교과목, 예를 들면 e-러닝의 이해와 적용, e-러닝 컨텐츠

10) http://hrd.incheon.ac.kr(인천대학교 창의인재개발학과) 
기획 및 설계, 인터넷 교육방송, 미티어리터러시 교육, 영상매체디자인 등과 같은 교과목을 개설 하여 학생들의 진로준비를 지원해야 할 것이다.

셋째, 다문화교육 관련 특성화이다. 다문화 교 육은 한국 사회에 국제결혼 이주자와 자녀, 재중 동포 및 외국인 근로자, 새터민 등과 같은 다양 한 하위문화집단의 증가로 인하여 서로간의 이질 성을 수용하고 공존할 수 있는 교육적 요구의 필 요성에 기인한다(장원순, 2009). 현재 다문화교육 전문가 양성을 목표로 특성화 교육과정을 운영하 고 있는 교육학과 1 개 대학을 제외하고는 일부 대학에서 다문화교육론, 다문화상담 등과 같은 기초과목을 개설하고 있다. 2011년 전국 다문화 학생수는 38,890 명으로 3 년만에 2 배로 증가하였 으며11), 최근 들어 다문화교육 관련 연구는 활발 하게 진행되고 있는 반면에 관련 다문화 학생을 지도할 수 있는 전문가 양성은 일부 대학 평생교 육원과 교육대학원 등에서 부분적으로 이루어지 고 있는 실정이다. 따라서 다문화교육 전문가를 양성하기 위한 특성화 교육과정 운영은 학생들의 진로분야를 확대하는데 기여할 수 있을 것으로 판단되며, 특성화를 위해서는 다문화 교육론, 다 문화 사회론, 다문화 상담, 다문화 교육지도 및 학급경영, 이중언어 발달 등과 같이 전문성을 신 장할 수 있는 다양한 교과목을 개발하여 교육과 정에 포함할 필요가 있다.

넷째, 진로진학상담교사 양성을 위한 특성화이 다. 진로진학상담교사는 '학생의 자기주도적인 진 로개발능력을 신장시키기 위해 진로교육과 관련 된 교과활동과 전문적인 수준의 학생 진로·진학 지도 관련 활동을 수행하는 교사'로 정의하듯이 (이종범 외, 2010), 기존의 진로상담부장이나 전 문상담교사와는 직무를 달리하는 교사로, 교원자 격검정령 시행규칙 제 2 조 2항 12 ) 별표에 '진로진

11) 연합뉴스(2011.08.13) '다문화가정 학생수 3년반에 2배 증가' 12) 제 2 조(자격증의 서식 및 표시과목) (1)「교원자격검정령」(이 하 "검정령"이라 한다) 제 3 조제 1 항에 따라 교육감 또는 대학. 산업대학·교육대학. 방송통신대학·국군간호사관학교 및 전문대
학상담 자격증 표시과목 신설로 새롭게 도입된 교과교사제도이다. 현재 과원 현직교사를 선발하 여 부전공 연수 후 2011년부터 일선 고등학교에 1 명씩 발령하여 학교 진로교육 총괄, 진로와 직 업 교과 수업, 진로진학 관련 학생 상담 등의 활 동을 하고 있으며, 2014년까지 전국의 모든 중·고 등학교에 배치할 예정이다13). 진로진학상담교사 에게는 전문가 행동, 노동시장 이해, 진로개발 측 정, 프로그램 개발·실행·관리, 요구분석 등과 같은 전문적 역량이 요구되는데(박용호, 2011), 단기간 의 부전공 연수로 직업 정체성과 전문성을 제고 하는데는 한계가 있다. 그러므로 정부는 현직교 사를 대상으로 선발하기보다는 진로진학상담교사 를 계획적으로 양성하여 직업 정체성과 전문성을 확보할 수 있는 대안을 중장기적 관점에서 마련 할 필요가 있다. 교육학 전공자가 진로진학상담 교사로 진출하기 위해서는 진로진학상담 관련 교 과목을 이수하여 교원자격증을 취득하고 신규교 원 임용시험 교과목에 포함되어야 하는 제도적 과제가 수반되어야 하므로 중·장기적 관점에서 접근할 필요가 있다. 현재 다문화교육 전문가로 의 진출은 수요가 적은 편이고, 진로진학상담교 사는 현직 교사를 대상으로 이루어지기 때문에 단기적인 성과를 지향하기보다는 중장기적인 관 점에서 접근하여 교육학 전공학생들의 진로를 개 발함으로써 진출분야의 폭을 넓히는데 의의를 찾 아야 할 것이다. 그 밖에도 진로상담사, 사회조사 분석사, 노인교육전문가, 교육프로그램 매니저 등 과 같은 교육서비스 관련 진로분야를 개발할 필 요가 있다.

학의 장(이하 "대학의 장"이라 한다)이 교원자격검정에 합격 한 자에 대하여 수여하는 교원자격증(이하 "자격증"이라 한 다)은 별지 제 1 호서식과 같다.

(2)중등학교 및 특수학교의 정교사 및 준교사의 자격증에 표시 할 담당과목과 검정령 제 4 조제 5 항의 규정에 의한 초등학교의 정교사의 자격증에 표시할 담당과목은 별표 1 과 같다. (3)실기교사의 자격증에 표시할 담당과목은 별표 2 와 같다.

13) 교육과학기술부 보도자료(2012.1.2), '진로진학상담교사' 1,529 명 부전공 자격 연수 시작 
<표 7> 진로분야와 관련된 교육과정 특성화 모델

\begin{tabular}{|c|c|c|}
\hline $\begin{array}{l}\text { 교과목 } \\
\text { 분야 }\end{array}$ & 특성화 관련 교과목 & 비고 \\
\hline $\begin{array}{l}\text { 기업체 } \\
\mathrm{HRD} \\
\text { 전문가 }\end{array}$ & $\begin{array}{l}\text { · 교육과 일의 세계, 인간관계 이론과 실제, } \\
\mathrm{HRD} \text { 와 성인교육, 기업교육공학의 실제, 교육 } \\
\text { 과 경제원리 등 } \\
\text { · 기업과 경영의 이해, } \mathrm{HRD} \text { 와 조직변화, 글로 } \\
\text { 벌 } \mathrm{HRD} \text { 동향, } \mathrm{HRD} \text { 와 창의성개발, } \mathrm{HRD} \text { 와 리 } \\
\text { 더십개발 등 } \\
\text { · 인간관계와 커뮤니케이션, 사이버 교수학습 } \\
\text { 체제개발, 경력개발과 조직개발, 자기개발과 } \\
\text { 셀프브래h딩, 직업교육과 실버산업, 기업교육 } \\
\text { 평가 등 } \\
\text { · } \mathrm{HRD} \text { 의 기초, } \mathrm{HRD} \text { 의 이론과 실제, 테크놀 } \\
\text { 로지와 } \mathrm{HRD}, \text { 교육공학과 } \mathrm{HRD,} \mathrm{HRD} \text { 교육니 } \\
\text { 즈 및 과제 분석, 기업교육 프로그램 평가론, } \\
\text { 기업 교육정보시스템 관리, } \mathrm{HRD} \text { 연구방법론, } \\
\text { 글로벌 } \mathrm{HRD} \text { 동향과 이슈 등 }\end{array}$ & $\begin{array}{l}\text { 연세대 } \\
\text { 교육학과 } \\
\text { 한양대 } \\
\text { 교육공학과 } \\
\text { 숭실대 } \\
\text { 교육공학과 } \\
\\
\text { 인천대 } \\
\text { 창의인재개발 } \\
\text { 학과 }\end{array}$ \\
\hline $\begin{array}{l}\mathrm{e} \text {-러닝 } \\
\text { 전문가 }\end{array}$ & $\begin{array}{l}\text { ·교육과 컴퓨터그래픽, 이러닝의 이해와 적 } \\
\text { 용, 인터넷 교육방송, 정보기술과 교육사업, 웹 } \\
\text { 기반 학습콘텐츠개발 } \\
\text { · 소프트웨어 개발 기초, 스토리보드개발, 컴 } \\
\text { 퓨터기반 수업개발, 교수이론과 모형, 이러닝 } \\
\text { 컨텐츠 기획 및 설계, 멀티미디어 수업개발, } \\
\text { 구성주의 수업설계, 인터넷 교육방송, 멀티미 } \\
\text { 디어 미학론 등 } \\
\text { ·교수설계스튜디오, 이러넝 설계, 이러닝 경 } \\
\text { 영전략, 미디어리터러시 교육 등 } \\
\text { · 교수매체제작, 영상매체 디자인, 그래픽스개 } \\
\text { 발, HCI디자인 및 웹컨텐츠 개발, 텔레비전 영 } \\
\text { 상제작, 이러닝 설계론, WBI 설계, 이러넝 개 } \\
\text { 발, 멀티미디어 정보센터관리 등 }\end{array}$ & $\begin{array}{c}\text { 건국대 } \\
\text { 교육공학과 } \\
\text { 안동대 } \\
\text { 교육공학과 } \\
\text { 이화여대 } \\
\text { 교육공학과 } \\
\text { 한양대 } \\
\text { 교육공학과 }\end{array}$ \\
\hline $\begin{array}{l}\text { 다문화 } \\
\text { 교육 } \\
\text { 전문가 }\end{array}$ & $\begin{array}{l}\text { 다문화 교육론, 다문화 사회와 교육, 다문화 } \\
\text { 교육지도 및 학급경영, 이중언어발달, 지역사 } \\
\text { 회인턴쉅 등 }\end{array}$ & $\begin{array}{l}\text { 조선대 } \\
\text { 교육학과 } \\
\text { 교육과정 참조 }\end{array}$ \\
\hline $\begin{array}{l}\text { 진로 } \\
\text { 진학 } \\
\text { 상담 } \\
\text { 교사 }\end{array}$ & $\begin{array}{l}\text { · 필수 : 진로교육개론, 청소년 진로특성 진단 } \\
\text { 및 활용, 진로진학지도 프로그램 활용 및 운 } \\
\text { 영, 진로체험과 지역사회, 직업세계와 직업정 } \\
\text { 보 탐색, 교육세계와 진학정보탐색, 진학지도 } \\
\text { 기법의 이론과 실제 } \\
\text { · 선택 : 진로포트폴리오 지도법, 창의 · 인성 } \\
\text { 진단 및 평가, 입학사정관제의 이해, 입시정보 } \\
\text { 관리 및 활용 등 } \\
\text { · 교직과목 : 진로진학상담교사 역량개발, 진 } \\
\text { 로와직업 교재연구, 진로와직업 교수학습 방 } \\
\text { 법, 진로교육 평가방법 등 }\end{array}$ & $\begin{array}{l}\text { 현직교사 } \\
\text { 부전공 } \\
\text { 연수과목 }\end{array}$ \\
\hline
\end{tabular}

\section{2. 학생 진로교육 모델 개발}

먼저, 학생 진로교육에 관한 모델을 제시하기 전에, 앞에서 살펴본 교육학과의 진로분야와 관 련된 교육과정 특성화 방안과 새롭게 제시한 진 로분야 등을 종합하여 교육학 전공학생의 진로분 야를 트랙별로 정리하면 <표 8>과 같다.

교육학 전공학생의 진로분야는 크게 교육직, 사회교육직, 연구 및 대학교원직, 공무원직 트랙 으로 구분할 수 있다. 첫째, 교육직 트랙은 복수 전공 및 부전공 교사, 도덕·윤리교사, 진로진학상 담교사 등으로의 진출을 목표로 한다. 둘째, 사회
<표 8> 교육학 전공학생의 진로분야 트랙

\begin{tabular}{|c|c|c|}
\hline 트랙 분은 & 진출 분야 & 진출 방법 등 \\
\hline \multirow{3}{*}{ 교육직 } & $\begin{array}{l}\text { 복수전공 } \\
\text { 및 부전공 } \\
\text { 교사 }\end{array}$ & $\begin{array}{l}\text { 국어, 영어, 수학 등 교과교육 복수전공 } \\
\text { 및 부전공 교직 진출 }\end{array}$ \\
\hline & 도덕·윤리 교사 & $\begin{array}{l}\text { 교육학과내 개설된 도덕·윤리 교과목 이 } \\
\text { 수 후 교원자격증 취득 }\end{array}$ \\
\hline & $\begin{array}{l}\text { 진로진학상담 } \\
\text { 교사 }\end{array}$ & $\begin{array}{l}\text { 중 · 고등학교 입시 카운슬러 역할을 수행 } \\
\text { 하나 현재 현직 교사를 부전공 연수하여 } \\
\text { 배치하고 있음 }\end{array}$ \\
\hline \multirow{4}{*}{ 사회교육직 } & 평생교육사 & $\begin{array}{l}\text { 평생교육관련 교과목 이수 후 평생교육시 } \\
\text { 설 근무 }\end{array}$ \\
\hline & $\begin{array}{l}\text { 기업체 } \mathrm{HRD} \\
\text { 전문가 }\end{array}$ & $\begin{array}{l}\text { 기업체 연수원, 인적자원개발실 등 교육관 } \\
\text { 련 부서 근무 }\end{array}$ \\
\hline & e-러닝 전문가 & $\begin{array}{l}\text { 교육용 소프트웨어 개발, 교수학습지원센 } \\
\text { 터(CTL) 등 근무 }\end{array}$ \\
\hline & $\begin{array}{l}\text { 다문화교육 } \\
\text { 전문가 }\end{array}$ & $\begin{array}{l}\text { 다문화교육사 자격증 취득 후 관련 직업 } \\
\text { 진출 }\end{array}$ \\
\hline $\begin{array}{l}\text { 연구 및 } \\
\text { 대학교원직 }\end{array}$ & 대학원 진학 & $\begin{array}{l}\text { 대학, 한국교육개발원, 한국교육과정개발 } \\
\text { 원, 대학교육협의회, 입학사정관, 대학 부 } \\
\text { 설 교수. 학습지원센터(CTL) 등 }\end{array}$ \\
\hline \multirow{2}{*}{ 공무원직 } & $\begin{array}{l}\text { 교육행정직 } \\
\text { 공무원 }\end{array}$ & $\begin{array}{l}5 \text { 급 및 } 7 \text { 급 국가직, } 9 \text { 급 국가직 및 지방직 } \\
\text { 으로 공개채용하며, 시 · 도 교육청 및 학 } \\
\text { 교 행정실에 근무하면서 학교 교육활동을 } \\
\text { 지원하는 직무 수행 }\end{array}$ \\
\hline & $\begin{array}{l}\text { 학교행정업무 } \\
\text { 전담직원 } \\
\text { (교육행정보조 } \\
\text { 교사) }\end{array}$ & $\begin{array}{l}\text { 교육과학기술부 도입예정, 서울 등 일부 } \\
\text { 시·도 교육청 도입하고 있으며, 학교 교 } \\
\text { 무실에 소속되어 각종 업무 처리 지원하 } \\
\text { 는 역할 수행 }\end{array}$ \\
\hline
\end{tabular}

교육직 트랙은 평생교육사, 기업체 $\mathrm{HRD}$ 전문가, $\mathrm{e}$-러닝 전문가, 다문화교육 전문가 등으로의 진출 을 목표로 하는데, 평생교육사 자격증 취득은 현 재 대부분의 교육학과 교육과정에 포함되어 있을 뿐 아니라 각 대학의 평생교육기관에서도 자격증 과정을 운영하고 있기 때문에 자격증 소지자의 희소성이 없다는 한계가 있으므로, 기업체 $\mathrm{HRD}$ 나 e-러닝 전문가 등과 같은 특성화 영역에 중점 을 둘 필요가 있다. 셋째, 연구 및 대학교원직 트 랙은 대학원 진학을 통해 석.박사 학위를 취득함 으로써 연구원과 대학 등에서 관련 분야 전문가 및 교수로 진출할 수 있다. 마지막으로 공무원직 트랙은 교육행정직 공무원과 학교행정업무 전담 직원으로 시·도교육청 및 지역교육지원청, 학교 행정실 등에서 학교 교육활동을 지원하는 역할을 하는데, 다른 행정적 공무원과는 달리 교육관련 기관에서 근무하기 때문에 교육학 지식이 직무수 행에 많은 도움이 되며 교육적 보람도 느낄 수 있는 직업이다. 
다음으로, 교육학 전공학생의 진로분야를 바탕 으로 학생 진로교육 모델을 제시하면 <표 9>와 같다. 구체적으로 살펴보면, 첫째, 진로 로드맵을 통해 학생들의 진로준비를 전체적으로 계획할 수 있는데, 1 학년 시기는 입학 및 진로탐색의 과정 을 거치고, 2 4학년 시기는 교육직, 사회교육직, 연구 및 대학교원직, 공무원직 등 희망하는 진로 분야별로 전문적 역량을 기르는 과정을 거치며, 최종적으로 졸업 및 취업에 도달할 수 있도록 구 상할 수 있다. 둘째, 단계별 진로교육 내용으로 는, 1 학년 시기는 학문 기초과목 이수, 진로 탐색 $\mathrm{I}$, 학생 요구분석 등의 과정을 거쳐 학년말 희 망진로 선택 및 지도교수를 배정하고, 2학년 시 기는 전공과목 이수, 진로탐색 $I$, 희망진로 과목 이수 I 등과 같이 본격적인 희망진로 준비를 시 작하며, 3학년 시기는 전공과목 이수, 진로탐색 III, 희망진로 과목 이수 II 등의 과정을 통해 진 학 및 취업 준비를 시작하고, 4 학년 시기는 진학 및 취업 준비를 마무리하는 순으로 이루어진다. 이 과정에서 학과 교육과정에서 선택과목의 다양 화, 이수과목을 1 학년은 기초과정 및 2 4학년은 심화과정으로 발전, 학생 맞춤형 지도교수 배정, 직업준비교육 강화 등과 같은 구체적 진로지도 방안을 모색해야 할 것이다.

\section{IV. 결 론}

본 연구에서는 학부과정 교육학과 및 교육학 관련학과의 설치, 진로분야, 취업 및 진학, 교육 과정 특성화 현황 등을 살펴보고, 이를 바탕으로 교육학 전공학생의 진로분야 발전방안을 탐색하 였으며, 그 결과는 다음과 같다.

먼저, 교육학과 및 교육학 관련학과의 현황 분 석을 통해 드러난 특징이다. 첫째, 취업률은 교육 학과에 비해 교육학 관련학과가 상당히 높았다.
$<$ 표 9> 학생 진로교육 모델

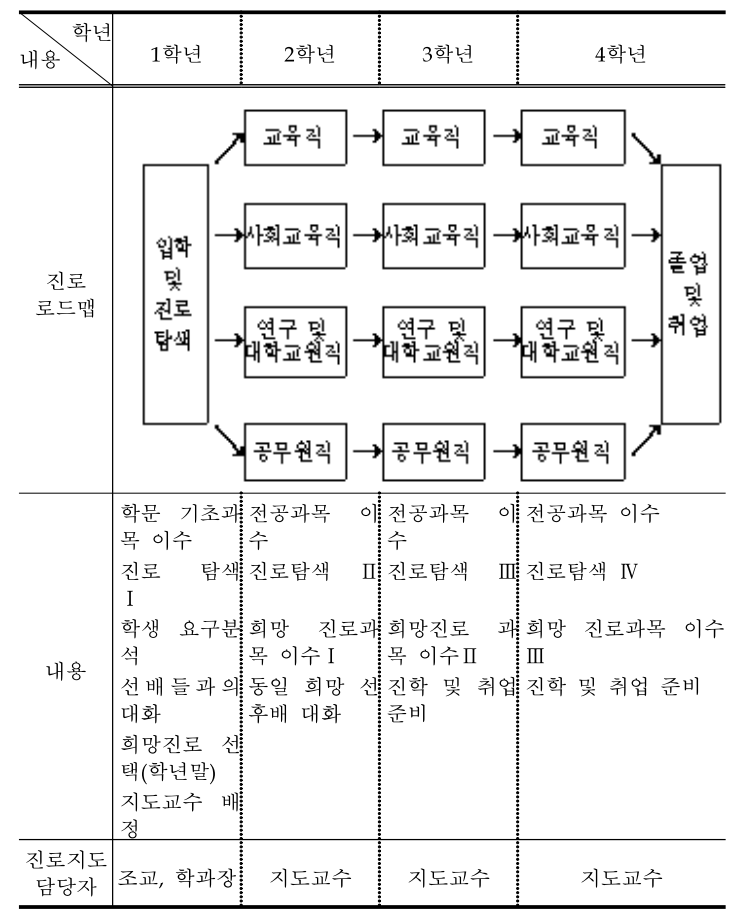

2011년 평균 취업률은 교육학과가 $35.0 \%$ 이지만 교육학 관련학과는 $56.6 \%$ 로 상당한 차이를 보였 다. 둘째, 교육과정 특성화는 교육학과에 비해 교 육학 관련학과가 활발하였다. 교육학과는 평생교 육사 자격증과 도덕·윤리 교원자격증 과정의 특 성화만 활발할 뿐 그 외 특성화는 거의 이루어지 지 않고 있는 반면, 교육학 관련학과는 개설학과 자체가 교육공학, 교육심리학, 평생교육학 등으로 이미 교육학과에 비해 특성화가 되어있음에도 불 구하고, 교육학 교원자격증, 평생교육사 자격증, 전문상담교사, 청소년지도사, 멀티미디어 연계, $\mathrm{HRD}$ 와 평생교육 연계 등 다양한 영역에서 특성 화가 활발하게 진행되고 있었다. 교육과정 특성 화 정도가 학생들의 취업과 어떻게 연결되는지 구체적으로 파악하기 어렵지만, 대학 및 학과의 교육 프로그램 특성화가 입학성적, 교육만족도, 취업률 등에 효과적이라는 선행연구(박광식, 2009; 오영재·박행모, 2003; 이주성, 2004)를 고려할 때 
교육학 관련학과의 교육과정 특성화가 학생들의 진로에 상당한 도움을 주고 있다고 짐작할 수 있 다.

다음으로, 교육학 전공학생의 진로관련 발전방 안을 논의한 결과이다. 첫째, 진로분야와 관련된 교육과정 특성화가 필요하다. 구체적으로는, 기업 체 HRD 및 e-러닝 관련 교육과정 특성화, 다문 화교육 전문가 및 진로진학상담교사로의 진출 가 능성 탐색이다. 기업체 HRD 및 e-러닝 관련 전 문가는 각 학과에서 교육학 전공학생의 주요 진 출분야로 안내하고 있으나 교육과정에는 거의 반 영되지 않고 있으므로, 교육과정 특성화를 통해 해당 분야로의 진출을 희망하는 학생의 전문성 제고에 도움을 줄 수 있을 것이다. 특히 e-러닝 관련 교육과정 특성화는 한국경제의 미래를 이끌 차세대 직업 55개(한국고용정보원, 2009)에 포함 된 U-러닝 교수설계자와 U-러닝 튜터를 양성하 여 학생들의 진로 다양화에 기여할 수 있을 것이 다. 다문화교육 전문가는 관련 분야에 대한 활발 한 연구에 비해 전문가 양성과 수요에 관한 제도 적 장치가 마련되지 않아 단기적인 관점보다는 중·장기적 관점에서 접근할 필요가 있으며, 진로 진학상담교사는 현직 과원교사를 선발하여 운영 하고 있으므로 전체적인 중등 교원 수급정책 등 관련된 여러 쟁점에 대한 추가적인 연구가 필요 하다. 둘째, 학생 진로교육 모델은 학년 중심으로 진로 로드맵을 단계화하여 체계적인 진로교육이 이루어질 수 있도록 제안하였으며, 이를 위한 전 제조건으로 교육학 진로분야를 교육직, 사회교육 직, 연구 및 대학교원직, 공무원직의 트랙으로 구 분하여 제시하였다. 특히 대학생을 대상으로 한 진로교육 교과목 및 프로그램이 직업기초능력, 진로성숙도, 진로결정 자기효능감, 진로준비행동 등과 같은 진로발달에 효과적이라는 선행연구(김 희수, 2012; 윤명희 외, 2007; 한미희, 2011; 허은 영, 2009)와 학부 전공이 취업에 미치는 영향이 매우 크다는 점(채창균·김태기, 2009)를 고려할 때, 학과 차원의 체계적인 진로교육은 교육학 전
공학생의 진로준비에 상당한 도움이 될 수 있을 것이다.

이상의 연구결과를 바탕으로 교육학 전공학생 의 진로분야에 대한 발전방안을 구체화하기 위한 과제를 제시하면 다음과 같다.

첫째, 학과 차원의 역할이다. 먼저, 학과는 학 생 진로를 고려한 표준교육과정을 개발하여, 학 생의 희망 진로에 따른 학년별 추천 교과목을 포 함하는 표준교육과정을 제시하여 학생들의 진로 지도를 체계적으로 실시할 필요가 있다. 이를 구 체화하기 위해서는 학생 진로와 역량 개발에 기 여할 수 있는 교과목 개발, 교육과정 개편을 통 한 다양한 선택과목 개설, 학생의 진로를 고려한 트랙형 교육과정 도입 등과 같은 교육과정상의 노력과, 학생들의 직업준비를 지원하기 위해 진 로관련 실무를 강화하는 방향으로 교육방법을 개 선할 필요가 있다. 다음으로, 학생들이 교직을 포 함한 다양한 진로탐색이 이루어지도록 진로지도 를 강화할 필요가 있다. 다양하고 체계적인 직업 준비교육은 그 동안 다소 학교교육학에 치중된 교육학의 학문적 필요성과 범위를 확대하는 기회 가 될 수 있을 것이다.

둘째, 대학 차원의 역할이다. 대학은 교육과정 특성화에 대한 인증평가제를 도입할 필요가 있 다. 교육과정 특성화 영역 중에서 평생교육사 과 정은 관련 교과목을 이수할 경우 2급 자격증을 받지만, 그 외 발전방안에서 제시한 기업체 $\mathrm{HRD}, \mathrm{e}$-러닝, 다문화교육 전문가 등과 같은 영역 은 교과목을 이수하더라도 전문성을 입증할 수 있는 자격증 제도가 없는 현실에서, 해당 특성화 교육과정을 운영하는 대학 또는 학과 차원의 인 증평가제를 도입하는 것을 고려해 볼 만하다. 이 와 같은 인증평가제는 대학이 운영하고 있는 학 생취업지원프로그램과 연계하여 맞춤형 진로지도 를 활성화하는 계기가 될 것이다.

셋째, 정부 차원의 역할이다. 정부는 기존의 교 과 담당교사들이 역할 수행에 한계를 보이고 있 는 진로진학지도, 학교폭력예방지도 등과 같이 
교육학 전공 지식을 중점적으로 활용할 수 있는 교직진출 경로를 개발할 필요가 있다. 교육학과 는 학부과정에 개설된 이후부터 현재까지 교사양 성을 주요 목표 중의 하나로 하고 있으며, 사범 대학에 소속된 비율이 높기 때문에 입학생들의 교직 희망비율이 높은 것도 일반적인 경향이다. 복수전공 또는 부전공과 같은 교직 진출 방법 외 에도 전공으로 이수한 교육학의 학문적 소양과 역량을 발휘할 수 있는 진로를 모색할 필요가 있 다.

\section{참고 문헌}

강성국 외(2009). 2009 학과(전공)분류 자료집, 한 국교육개발원, 통계자료 SM 2009-08.

강승희(2010). 공학전공 대학생의 전공학과 만족 도와 진로결정 효능감 및 진로태도 성숙간의 관계, 수산해양교육연구 22(2), 151 164.

교육과학기술부(2011). 2011년 진로진학상담교사 부전공자격연수 운영 계획, 교육과학기술부.

교육과학기술부(2012). '진로진학상담교사' 1,529 명 부전공 자격 연수 시작, 교육과학기술부 보 도자료(2012.1.2).

김성국(2000). 인적자원개발을 위한 대학의 전문 직업교육 강화방안, 경영논총 18(1), 15 34.

김인규(2009). 학부 상담학과 교육의 현황과 발전 방안 연구, 상담학연구 10(2), 793 811.

김재춘 - 김재현(2008). 교육학과 교육과정의 편성 실태 분석 및 개선 방안 탐색, 교육과학연구 39(3), 111 138.

김현우(1997). 교육학과 교육과정의 편성 현황 및 개선 과제, 교육과학연구 2, 1 21.

김홍백 - 김상태(2005). 체육 및 스포츠관련 학과 의 현황과 과제 및 발전 방안, 한국스포츠리서 치 16(2), 735 746.

김희수(2012). 대학의 교과목을 통한 진로교육 프 로그램이 직업기초능력 향상에 미치는 효과 연 구, 진로교육연구 25(1), 73 89.

목진휴 - 허만형 - 김희경 - 장덕희 · 김덕기(2009). 대학의 직업교육 평가, 한국직업능력개발원, 기 본연구 2009-50.

박광식(2009). 대학의 특성화 교육서비스가 학습 자 만족과 취업기회에 미치는 영향, 한국비즈
니스리뷰 2(1), 25 45.

박병수 - 강일권(2011). 수 - 해운계 대학 승선학과 졸업생의 해상직 취업 진로분석, 수산해양교육 연구 23(4), 779 785.

박용호(2011). 진로진학상담교사의 역량: 교육적 요구분석을 중심으로, 진로교육연구 24(1), 117 136.

박종운 - 차타순(2009). 수 · 해양대학생들의 진로 선택과 진로탐색장애에 관한 연구, 수산해양교 육연구 21(3), 459 469.

박철홍(2006). 평생학습사회를 지향하는 정부의 대학직업교육정책에 대한 교육철학적 검토, 교 육철학 35, 49 69.

송숙경 - 김현정 - 이은화(2010). 교육학과 전공교 육과정의 조직요소 분석: 교육과정 교과를 중 심으로, 수산해양교육연구 22(4), 477 489.

오경희(2011). 학부 교육학 관련학과 현황과 시사 점, 제9회 효원교육포럼 발표집, 87 107.

오영재 - 박행모(2003). 지방 사립대학의 특성화 전략과 그 효과에 관한 연구, 교육행정학연구 21(1), 239 268.

윤명희 - 이경선 - 서희정(2007). 여대생 특화 진로 교과목의 효과 분석, 진로교육연구 20(2), 91109.

이종범 - 최동선 · 고재성 - 이혜숙(2010). 진로진학 상담교사 양성을 위한 표준교육과정 개발연구, 교육과학기술부.

이종승(2011). 교원양성과정에 있어서 교육학의 위상, 2011 한국교육학회 춘계학술대회 발표집, 3-21.

이종호(2008). 수산 - 해운 전문계열 사범계 학과 의 발전 방향, 부경대학교 석사학위논문.

이주성(2004). 지방대학 특성화 사업이 공학교육 에 주는 효과, 공학교육연구 7(1), 30 39.

이주원 · 이정미 · 나원배(2011). 해양계열 대학생 의 성적 특성과 취업률의 서술통계해석, 수산 해양교육연구 23(4), 615 625.

장원순(2009). 한국사회에 적합한 다문화교사교육 과정에 관한 연구, 사회과교육 48(1), 57 79.

정용상(2011). 학부 법학교육의 발전을 위한 정책 적 과제, 교육법학연구 23(2), 213 237.

조경호(2005). 행정학과 학부 교육과정 분석과 발 전 방안 연구, 한국인사행정학회보 4(2), 143 158.

채창균 - 김태기(2009). 대졸 청년층의 취업 성과 결정 요인 분석, 직업교육연구 28(2), 89 107. 
최용범 - 최은수(2010). 조직성과 지원을 위한 $\mathrm{HRD}$ 의 기능과 역할, 평생교육· $\mathrm{HRD}$ 연구 6(1), 23 43.

최임수·최경식(2010). 전국 대학 세무학과 현황 및 발전방안, 조세연구 10(2), 437 475.

한국고용정보원(2009). 한국경제 미래 이끌 차세 대 직업 55개 선정, 한국고용정보원 보도자료 (2009.6.4).

한국직업능력개발원(2011). 한국의 인적자원개발 지표 2011, 한국직업능력개발원, 연구자료 2011-25.

한미희(2011). 대학생을 위한 진로교육 교과목의 개발 및 효과, 진로교육연구 24(2), 95 113.

허은영(2009). 대학생 대상 진로지도 교과목 운영 의 효과, 직업교육연구 28(4), 77 94.

황정규(1991). 교육학의 성격과 교육학 교육, 교 육학연구 29(3), 1 10.

경향신문(http://www.khan.co.kr)

교육과학기술부통계서비스(http://cesi.kedi.re.kr) 대학알리미(http://www.academyinfo.go.kr) 동의대학교 평생교육학과

(http://lifelonged.deu.ac.kr)

서울여자대학교 교육심리학과

(http://www.swep.co.kr)

안동대학교 교육공학과

(http://home.andong.ac.kr/edutech)

연합뉴스(http://www.yonhapnews.co.kr)

이화여자대학교 교육공학과

(http://home.ewha.ac.kr/ et).

인천대학교 창의인재개발학과

(http://hrd.incheon.ac.kr)

한국교육개발원 교육정책네트워크정보센터

(http://edpolicy.kedi.re.kr)

- 논문접수일 : 2012년 08월 30일

- 심사완료일 : 1차 - 2012년 09월 15일

- 게재확정일 : 2012년 09월 17일 